\title{
The Amazon Soy Moratorium: How companies, NGOs and government leveraged market forces to tackle deforestation in the
} Amazon

Matthew McFall

Carolyn Rodehau

David Wofford

\section{Recommended Citation}

McFall, Matthew, Carolyn Rodehau, and David Wofford. 2017. "The Amazon Soy Moratorium: How companies, NGOs and government leveraged market forces to tackle deforestation in the Amazon," case study. Washington, DC: Population Council, The Evidence Project. 


\title{
The Amazon Soy Moratorium
}

\author{
How companies, NGOs and government leveraged market forces to tackle \\ deforestation in the Amazon
}

Brazil's Soy Moratorium (SoyM) was the first voluntary, zero-deforestation agreement implemented in the world, and set the stage for supply-chain governance initiatives for other commodity drivers of deforestation, such as beef and palm oil (Gibbs et al. 2015). From the late 1990s through 2004, Amazon deforestation became far more sensitive to global influences, as commodity market conditions and technological advances favored the first large-scale expansion of soy and other mechanized crops into the region (Nepstad 2014). Between 2001 and 2006,

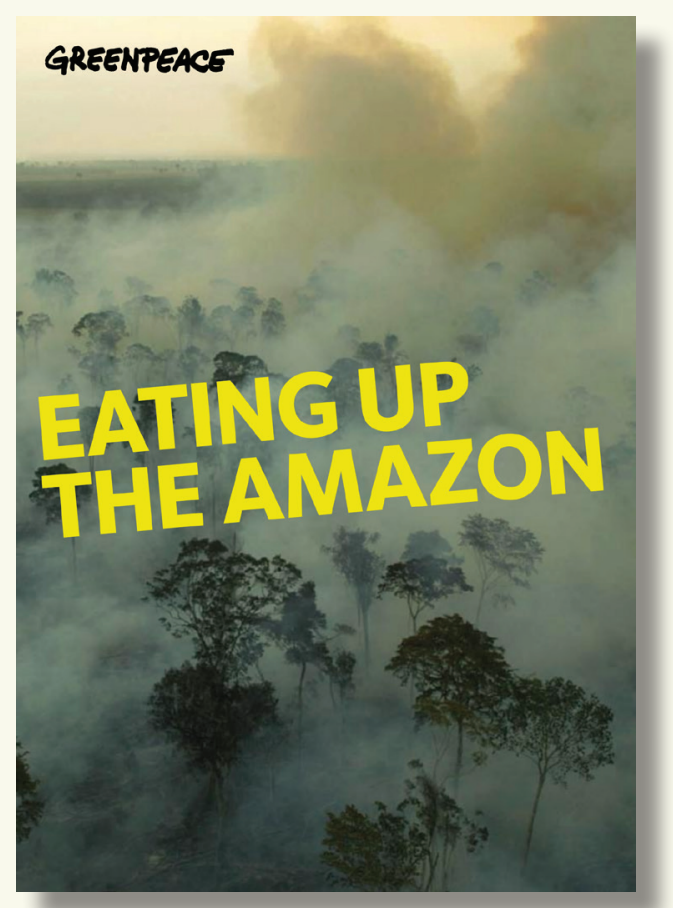
soybean fields expanded by one million hectares (Mha) in the Amazon biome, and direct conversion of forests to soy production contributed to record deforestation rates (Gibbs et al. 2015). Until 2006, Brazil had been the world leader in tropical deforestation, clearing an average of 19,500 km2 annually from 1996 to 2005. This forest conversion to pasture and farmland released 0.7 to $1.4 \mathrm{GtCO} 2 \mathrm{e}$ (billion tons of $\mathrm{CO} 2$ equivalents) per year to the atmosphere (Nepstad 2014).

In 2006, Greenpeace released a report entitled "Eating up the Amazon," in which it laid out the problem of commodity-driven deforestation in the Amazon and specifically targeted major agribusiness traders such as Cargill, ADM, and Bunge, but also McDonald's, as a buyer of soy from these traders (Greenpeace International 2006). Greenpeace chose to focus its attention on McDonald's in the report and campaign activities - which included activists protesting in chicken costumes at McDonald's restaurants in Europe and a blockade activists set up at the soybean port of Santarém, Pará on the Amazon River (Brown 2013) - despite the fact that its supply chain represented less than 0.5 percent of soy purchasing from Brazil (Langert 2016). The goal was to get McDonald's, a major global corporation with powerful brand recognition, to pressure its suppliers, namely Cargill, to stop contributing to soy-related deforestation in the Amazon. Greenpeace's strategy was to move McDonald's on the deforestation issue, believing that others would then follow their example.

This case study is part of a broader analysis on key lessons women's health advocates can learn from the environmental movement on effective strategies for driving changes in corporate policies and practices. To read the full brief and other case studies, go to http://evidenceproject.popcouncil.org/?p=3034. 
To the surprise of Greenpeace, not only did McDonald's move on the issue, but it also helped convene and recruit other actors, including Cargill, to meet and work together to solve the problem. In response to pressure from Greenpeace and other NGOs, as well as the recruitment and convening power of McDonald's, major soybean traders committed to an agreement, later known as the Soy Moratorium, not to purchase soy grown on lands deforested after July 2006 in the Brazilian Amazon. The moratorium was renewed annually starting in 2008 and, as of May 2016, it has been renewed indefinitely or, as the renewal document says, until it is no longer needed (Estrada Patino 2016).

At the time, the leader of the Greenpeace Amazon campaign, Paulo Adario, attributed the rapid response and success to the simplicity of the demand, asserting that "Simplicity was the key ingredient. Everyone could understand it...We drew a line in the sand and said 'No deforestation here,' backed by respecting indigenous people's rights, "and no slavery." (Langert 2016) In the two years prior to the SoyM, nearly 30 percent of soy expansion occurred through deforestation, rather than replacement of pasture or other previously cleared lands. After the SoyM, deforestation for soy dramatically decreased, falling to only about 1 percent of expansion in the Amazon biome by 2014, even though soy area increased in the area by 1.3 Mha (Gibbs et al. 2015). Farms violating the SoyM were identified using a satellite and airborne monitoring system developed by industry, NGOs, and government partners, and were blocked from selling to SoyM signatories.

According to Gibbs et al. (2015), the success of the SoyM is due to five overarching factors:

1. A limited number of soy buyers exert considerable control of soy purchasing and financing (these include multinational agribusiness companies such as Cargill, ADM, Bunge, and Louis Dreyfuss)

2. Simple compliance requirements

3. Streamlined and transparent monitoring and enforcement systems

4. Simultaneous efforts by the Brazilian government to reduce deforestation

5. Active participation by NGOs and government agencies

While the SoyM is a widely heralded success story of the environmental movement, some remain skeptical of its long-term efficacy and replicability beyond Brazil, given the unique enabling circumstances. While market-led dynamics were essential to the success of the SoyM, the role of the Brazilian government's sustained focus on protecting the Amazon cannot be overlooked. Political priority, allocation of government resources, and the implementation of a monitoring and surveillance system created an enabling environment for the SoyM. The national government also played a critical role in the enforcement of the moratorium. While restrictions on access to markets and finance succeeded in decelerating deforestation, these did not address the region's need for private investment, innovation, enterprise, and land titling, which is fundamental to landholders' ability to access credit. Thus, there may be unintended consequences for farmers' negotiating power with purchasers and the engagement of livestock and agriculture businesses that have important roles in deforestation.

Nevertheless, the success of SoyM has been widely touted, and there is clear evidence that the moratorium has curbed soy-driven deforestation in the Amazon to near zero - only about 0.8 percent of deforestation can be attributed to soy as of 2016 (Barrett 2016) - while also helping reduce deforestation in the Amazon overall, and serving as a model for the 2009 moratorium on deforestation for cattle ranching. 


\section{REFERENCES}

Barrett, Kelli. “Soy Sheds Its Deforestation Rap.” 2016. GreenBiz. https:// www.greenbiz.com/article/soy-sheds-its-deforestation-rap. Accessed March 312017.

Brown, J. Christopher, and Matthew Koeppe. "Debates in the Environmentalist Community: The Soy Moratorium and the Construction of Illegal Soybeans in the Brazilian Amazon," 2013. https://kuscholarworks.ku.edu/ handle/1808/10906.

Estrada Patino, Rodrigo. "Brazilian Soy Moratorium Renewed Indefinitely." 2016. Greenpeace. http://www.greenpeace.org/usa/news/brazilian-soy-moratorium-renewed-indefinitely/. Accessed March 312017.

Gibbs, H. K., L. Rausch, J. Munger, I. Schelly, D. C. Morton, P. Noojipady, B. Soares-Filho, P. Barreto, L. Micol, and N. F. Walker. "Brazil's Soy Moratorium.” 2015. Science 347, no. 6220: 377-78. doi:10.1126/science. aaa0181.
Greenpeace International. “Eating Up the Amazon,” 2006. www.greenpeace.org/forests. Accessed March 312017.

Langert, Bob. “Greenpeace, McDonald's and the power of collaboration.” 2016. GreenBiz. https://www.greenbiz.com/article/greenpeace-mcdonalds-and-power-collaboration. Accessed March 312017.

Nepstad, D., D. McGrath, C. Stickler, A. Alencar, A. Azevedo, B. Swette, T. Bezerra, et al. "Slowing Amazon Deforestation through Public Policy and Interventions in Beef and Soy Supply Chains." 2014. Science 344, no. 6188: 1118-23. doi:10.1126/science.1248525.

\section{THE EVIDENCE PROJECT}

Population Council 4301 Connecticut Avenue NW

Suite 280

Washington, DC 20008 USA

tel +12022379400

evidenceproject@popcouncil.org
The Evidence Project is made possible by the generous support of the American people through the United States Agency for International Development (USAID) under the terms of cooperative agreement no. AID-OAA-A-13-00087. The contents of this document are the sole responsibility of the Evidence Project and Population Council and do not necessarily reflect the views of USAID or the United States Government.

Evidence

The Evidence Project uses implementation science-the strategic generation, translation, and use of evidence-to strengthen and scale up family planning and reproductive health programs to reduce unintended pregnancies worldwide. The Evidence Project is led by the Population Council in partnership with INDEPTH Network, International Planned Parenthood Federation, PATH, Population Reference Bureau, and a University Research Network.

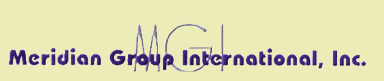

Meridian Group International, Inc. is a woman-owned, small business that works with the private and public sectors to create innovative programs and partnerships that benefit both business and society. Meridian Group International, Inc. is a partner of the Evidence Project and the Cambodia Worker Health Coalition.

Suggested Citation: McFall, Matthew, Carolyn Rodehau, and David Wofford. 2017. "Oxfam's "Behind the Brands" Campaign," Case Study. Washington, DC: Population Council, The Evidence Project.

(c) 2017 The Population Council, Inc. 